\title{
PENCARIAN TEMA SEJENIS SINOPSIS NOVEL BAHASA INDONESIA DENGAN MENGGUNAKAN GVSM
}

\author{
Munif ${ }^{1}$, Endang Setyati ${ }^{2}$, Yosi Kristian $^{3}$ \\ ${ }^{1}$ Jurusan Teknik Informatika, Fakultas Teknik, Universitas Islam Lamongan \\ ${ }^{2}$ Jurusan Teknologi Informasi, Fakultas Sains dan Teknologi, Institut Sains dan Teknologi Terpadu Surabaya \\ ${ }^{3}$ Jurusan Teknologi Informasi, Fakultas Sains dan Teknologi, Institut Sains dan Teknologi Terpadu Surabaya \\ E-mail: munif@unisla.ac.id,endang@stts.edu,yosi@stts.edu
}

\begin{abstract}
ABSTRAKS
Tujuan utama dalam penelitian ini adalah untuk membantu memberikan informasi dokumen yang relevan sehingga mempermudah dalam melakukan pencarian novel dan lebih mengetahui isi dari sebuah novel. Output dari sistem yang dibangun ini adalah daftar sinopsis novel bahasa Indonesia beserta judul novel yang relevan sesuai dengan keyword yang diinputkan. Dataset yang digunakan dalam penelitian ini adalah synopsis novel bahasa indonesia yang didapatkan dengan cara crawling dan sudah dipisahkan dalam bentuk teks dokumen. Dataset berjumlah lebih dari 1500 record. Selajutnya dataset tersebut dilakukan pre-prosesing yang meliputi case folding, tokenizing, filtering dan stemming. Proses pencarian dilakukan dengan metode Generalized Vector Space Model sedangkan proses pengklasifikasian dilakukan dengan metode Nä̈ve Bayes Classifier. Uji coba sistem dilakukan dengan menggunakan 300 data uji, dengan rincian 150 data uji untuk pencarian dan 150 untuk uji klasifikasi. Hasil dari sistem yang dibuat berupa ranking dokumen relevan berdasarkan urutan nilai cosine similarity dan juga menampilkan hasil klasifikasi sinopsis novel. Uji coba sistem pencarian yang dilakukan menghasilkan nilai recall yaitu $90 \%$ dan precision $85 \%$ sedangkan uji coba klasifikasi menghasilkan nilai akurasi sampai dengan $86 \%$.
\end{abstract}

Kata Kunci: Sinopsis, Generalized Vector Space Model, Nä̈ve Bayes Classifier, Cosine Similarity.

\begin{abstract}
The main purpose of this research is to help provide relevant document information to make it easier to find novels and find out more about the contents of a novel. The output of the system being built is a list of synopsis of Indonesian novels along with relevant novel titles according to the entered keywords. The data set used in this study is a synopsis of Indonesian novels obtained by crawling and is already in the form of document text. The dataset may be more than 1500 records. The next dataset is pre-processed which includes case folding, tokenizing, filtering and stemming. The weighting process is carried out using the Generalized Vector Space Model method, while the classification process is carried out using the Nä̈ve Bayes Classifier method. System testing is carried out using 300 test data, with details of 150 test data for searching and 150 for classification testing. The results of the system are made in the form of ranking the relevant documents based on the order of the cosine similarity values and display the classification results of the novel synopsis. The search system testing performed resulted in a recall value of $90 \%$ and accuracy of $85 \%$, while the classification test resulted in an accuracy value of up to $86 \%$.
\end{abstract}

Kata Kunci: Synopsis, Generalized Vector Space Model, Nä̈ve Bayes Classifier, Cosine Similarity.

\section{PENDAHULUAN}

\subsection{Latar Belakang}

Pencarian informasi atau yang dikenal dengan istilah temu balik informasi (Information Retrieval) merupakan sistem yang dapat digunakan untuk menemukan informasi yang relevan dengan kebutuhan dari penggunanya secara otomatis dari suatu koleksi informasi (Mandala dan Setiawan, 2002). Sistem temu kembali menerima masukan (input) berupa kata-kata kunci (keyword) dari informasi yang dicari, dan dalam waktu yang relatif singkat sistem akan menampilkan daftar dokumen yang sesuai dengan kebutuhan informasi pengguna (Hendra Bunyamin dan Chathalea, 2008).

Generalized Vector Space Model merupakan perluasan dari vector space model (vsm) yaitu dengan menambahkan jenis informasi tambahan, disamping term, dalam merepresentasikan dokumen (Jasman Pardede dkk, 2013). Sistem temu kembali dengan generelized vector space model (gvsm) merepresentasikan dokumen dengan similaritas vector terhadap semua dokumen yang ada. deskripsi ringkas mengenai gvsm adalah linierly independent. Generalized Vector Space Model (gvsm) menghindari pengasumsian dengan penggunaan dokumen-dokumen sebagai dasar ruang vector dari pada term. Dalam "dual space" suatu dokumen direpresentasikan oleh suatu vector dimana dimensinya merujuk terhadap dokumen (Baeza, 1999).

Naïve bayes classifier merupakan pengklasifikasian dengan metode probabilitas dan statistik yang memprediksi peluang di masa depan berdasarkan pengalaman di masa sebelumnya sehingga dikenal sebagai teorema bayes. Secara sederhana, naïve bayes menggunakan kemiripan fitur antara data training dan data testing dimana nantinya akan diambil class yang paling mirip dari data training tersebut (Junaedi widjojo, 2012). Kelebihan dari naïve bayes adalah sederhana namun memiliki tingkat akurasi yang cukup tinggi. 
Sinopsis novel merupakan bagian penting dari sebuah novel, setiap novel memiliki sinopsis yang dapat memudahkan pembaca untuk lebih memahami karakter dan isi cerita yang ada dalam novel itu sendiri. Dalam penelitian kali ini penulis membuat sistem aplikasi yang dapat memberikan informasi teks sinopsis novel beserta klasifikasinya berdasarkan keyword yang dimasukkan pengguna pada system.

\subsection{Tujuan dan Manfaat}

Adapun dari rumusan masalah diatas, maka penelitian ini memiliki tujuan dan manfaat sebagai berikut.

a. Mengimplementasikan dan mengevaluasi hasil temu kembali dalam dokumen.

b. Membuat system information retrieval yang dapat memberikan informasi teks sinopsis novel berdasarkan keyword yang diinputkan oleh pengguna.

c. Mengklasifikasikan teks sinopsis novel dalam 5 kategori yaitu : novel anak, novel remaja, novel islami, novel fantasi dan novel misteri berdasarkan keyword.

Sedangkan manfaat dari penelitian ini adalah dapat mempermudah bagi user untuk menemukan judul dan sinposis novel dengan hasil akurat dan cepat serta mengetahui klasifikasi novel berdasarkan sinopsisnya.

\subsection{Metode Penelitian}

Metode penelitian yang digunakan dalam penelitian ini adalah sebagai berikut :

a. Pengumpulan Data

Proses pengumpulan data sinopsis dilakukan dengan menggunakan metode crawling dari website penjulaan buku online. Crawling dibangun sendiri dengan menggunakan bahasa pemrograman PHP.

b. Studi Literatur

Dengan mempelajari buku-buku referensi dan jurnal yang berkaitan dengan permasalahan penelitian yang diangkat serta mencari solusi yang terbaik. Topik bahasan utama yang dibutuhkan diantaranya adalah Information Retrival, GVSM (Generalized Vector Space Model) serta Nä̈ve Bayes Classifier (NBC).

c. Analisa

Melakukan uji coba secara teoritis terhadap masalah yang diangkat guna menganalisa apakah rancangan algoritma yang digunakan dapat menghasilkan solusi yang sesuai dengan tujuan penelitian.

d. Implementasi

Membuat program dari hasil rancangan algoritma yang telah dibuat untuk mengimplementasikan serta membuktikan bahwa hasil analisa secara teoritis yang telah dilakukan benar-benar sesuai yang diharapkan.

e. Pengujian
Pengujian dilakukan untuk melihat apakah data yang telah menjadi input akan diproses sesuai dengan output yang diharapkan. Hal ini juga dilakukan untuk mengevaluasi apakah metode yang diusulkan mampu menjawab tujuan yang telah diusulkan.

f. Dokumentasi

Merupakan langkah akhir, penyusunan laporan mulai dari latar belakang permasalahan sampai dengan pengambilan kesimpulan akan dijelaskan dalam tahap dokumentasi ini.

\section{ANALISA DAN DESAIN SISTEM}

\subsection{Analisa Desain Sistem}

Sistem yang dibangun untuk melakukan penelitian ini adalah sebuah sistem yang dapat digunakan sebagai mesin pencarian sinopsis novel bahasa indonesia serta dapat mengklasifikasikan sinopsis berdasarkan kategori yang sudah ditentukan.

Arsitektur sistem digunakan untuk menggambarkan sistem kerja yang digunakan dalam proses analisa dan implementasi. Dengan arsitektur sistem dapat dilihat alur sistem secara lengkap, adapun arsitektur sistem dari keseluruhan sistem dapat ditunjukkan pada Gambar 1.

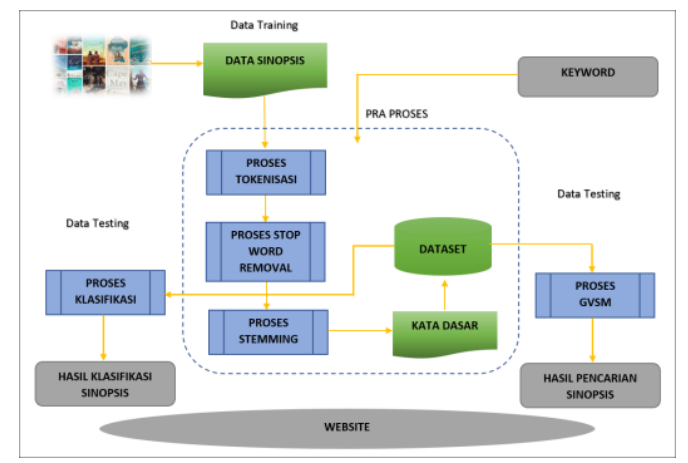

Gambar 1. Desain arsitektur sistem pencarian sinopsis novel dan klasifikasi sinopsis novel

Berikut ini adalah penjelasan dari arsitektur sistem pada Gambar 1:

1. Proses awal dari sistem ini adalah proses pengambilan data dari website bukukita.com atau crawling yang dibangun dengan menggunakan Bahasa pemrograman php sehingga disimpanlah menjadi sebuah data mentah pada database Mysql.

2. Preprosessing dilakukan untuk membentuk dataset dalam basis data. Diantaranya proses tersebut adalah :

a) Proses tokenisasi, yaitu memisahkan setiap kata dalam satu dokumen sinopsis sehingga terbentuk menjadi sebuah kumpulan kata.

b) Proses berikutnya adalah Stopword removal, yaitu menghilangkan kata-kata yang dianggap tidak perlu dan sering muncul di setiap dokumen. 
c) Berikutnya dilakukan proses stemming, yaitu proses pembentukan kata dasar dengan cara menghilangkan imbuhan disetiap kata.

d) Setelah terbentuk menjadi kata dasar, barulah data tersebut disimpan kedalam database untuk dijadikan sebagai dataset yang akan diproses oleh sistem.

3. Dari dataset yang sudah terbentuk, selanjutnya proses pencarian sinopsis dilakukan dengan menggunakan metode Generalized Vector Space Model.

4. Jika terdapat data sinopsis baru yang belum memiliki kategori maka sistem akan mengklasifikasikan data tersebut menggunakan metode nä̈ve bayes.

\subsection{Analisa Kebutuhan Data}

Data sinopsis novel yang digunakan dalam penelitian ini terdapat lebih dari 1500 sinopsis, hasil crawling yang dibangun sendiri dengan bahasa pemrograman php. Data synopsis diambil dari website penjualan buku online. Sinopsis novel terdiri dari beberapa jenis novel diantaranya, novel anak, islami, remaja, fantasi dan misteri. Adapun rincian data yang digunakan dalam penelitian ini dijelaskan pada tabel 1.

\section{Tabel 1. Rincian data penelitian}

\begin{tabular}{|c|l|c|}
\hline No & Kategori Novel & Jumlah Sinopsis \\
\hline 1 & Novel Anak & 350 \\
\hline 2 & Novel Remaja & 350 \\
\hline 3 & Novel Fantasi & 300 \\
\hline 4 & Novel Islami & 200 \\
\hline 5 & Novel Misteri & 300 \\
\hline \multicolumn{2}{|c|}{ Jumlah Sinopsis } & 1500 \\
\hline
\end{tabular}

Adapun contoh sinopsis novel yang telah berhasil dikumpulkan menggunakan crawling dijelaskan pada gambar 2 .

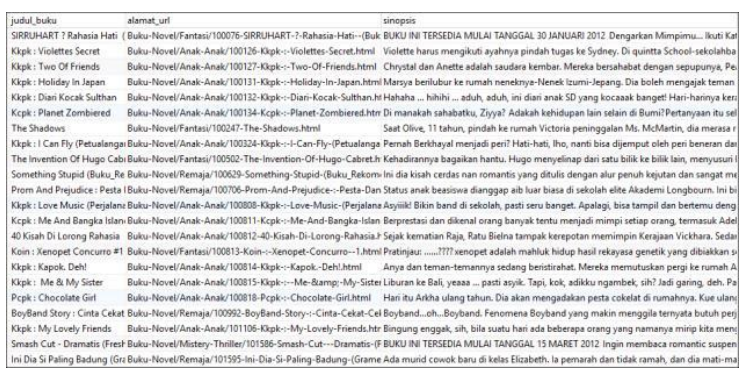

Gambar 2. Data sinopsis hasil crawling

\subsection{Analisa Kebutuhan User}

Dilihat dari sisi user maka sistem yang dibangun ini bertujuan untuk memudahkan user atau masyarakat umum dalam mencari judul novel beserta sinopsisnya, dan seperti yang telah dijelaskan sebelumnya dalam mencari judul novel serta sinopsis novel dapat dicari dari Queri sesuai yang diinputkan oleh user.
User hanya memerlukan sistem untuk melakukan pencarian saja akan tetapi sistem ini juga memiliki sub sistem untuk pre-prosessing. Dimana sub sistem ini hanya dapat digunakan oleh admin sistem.

Sebelum melakukan pre-prosessing admin perlu melakukan analisa lebih lanjut terhadap setiap tahapan pre-prosessing. Seperti pada tahap pemilihan stopwords, maka admin perlu melakukan analisa lanjutan untuk memilih kata- kata yang dianggap stopword dengan melihat objek penelitian yang dibangun ini. Dalam pre-prosessing ini admin hanya perlu melakukan satu kali pre-prosessing.

\subsection{Analisa Kebutuhan Software}

Untuk membangun sistem ini digunakan beberapa software, yaitu :

a) Windows $\mathrm{XP} / 7 / \mathrm{W} 10$

Sistem operasi atau sistem dasar untuk mengoperasikan sebuah alat elektronik dalam hal ini adalah komputer. Karena merupakan sistem dasar maka dapat ditambahkan program aplikasi seperti, Microsoft Word termasuk Xampp dan lainnya.

b) PHP

PHP adalah sebuah skrip pemrograman yang terletak dan dieksekusi di server. Salah satunya adalah untuk menerima, mengolah dan menampilkan data dari dan ke sebuah situs. Data yang diterima akan diolah disebuah program database server (program database yang terletak di sisi server, MySql contohnya) untuk kemudian hasilnya ditampilkan kembali dalam layar browser sebagai situs. Dengan demikian PHP dapat membuat sebuah sits menjadi dinamis karena data situs tersebut dapat selalu berubah sesuai dengan permintaan.

c) Database MySql

MySql merupakan sebuah perangkat lunak sistem manajemen basis data SQL (Database Manajemen Sistem) atau DBMS yang multithread dan multi user.

\section{PEMBAHASAN}

\subsection{Generalized Vector Space Model (GVSM)}

Generalized Vector Space Model (GVSM) merupakan pengembangan dari metode Vector Space Model (VSM). Algoritma GVSM termasuk kedalam Algebraic model, dimana algebraic model merupakan salah satu dari 3 model besar information retrieval. Pada information retrieval yang menggunakan algebraic model, seluruh dokumen dan query direpresentasikan menjadi vektor, untuk menemukan similarity antara dokumen dan query maka nilai skalar antara vektor query dan vektor dokumen akan dikaitkan sehingga muncul nilai skalar sebagai acuan pengurutan dokumen (Tsatsaronis, G. dan Panagiotopoulou, 2009 Hal. 7078).

Algoritma Generalized Vector Space Model yang dibahas menggunakan konsep ruang vektor. 
Masukan dari user dan kumpulan dokumen diterjemahkan menjadi vektor-vektor. Kemudian vektor-vektor tersebut dikenakan operasi perkalian titik dan hasilnya menjadi acuan dalam menentukan relevansi masukkan pengguna (query) terhadap kumpulan dokumen.

Menurut Baeza terdapat beberapa langkah atau proses untuk mendapatkan hasil pencarian sesuai dengan query yang dimasukkan, yang disebut sebagai algoritma Generalized Vector Space Model.

a) Membuang kata depan dan kata penghubung

b) Menggunakan stemmer pada kumpulan dokumen dan query. Tahap ini biasa disebut sebagai tahap preprocessing

c) Menentukan pola minterm untuk mengetahui pola frekuensi kata. Panjang minterm ini didasarkan pada banyak kata yang diinput pada query. Kemudian diubah menjadi vector orthogonal sesuai dengan pola minterm yang muncul

d) Melakukan perhitungan kemunculan kata yang terdapat pada dokumen berdasarkan kata kunci. Pada penelitian ini menggunakan rumus TF-IDF.

e) Menghitung index term menggunakan persamaan 1

$\overrightarrow{K_{1}}=\frac{\sum_{\forall r \text { gi }(M r)=1} C i, r_{n} \overrightarrow{M r}}{\sqrt{\sum_{\nabla r, g i(M r)}=1}\left(i, r^{2}\right.}$

Dimana :

$\overrightarrow{K_{\mathrm{I}}}:$ Index term

$\overrightarrow{M_{y}}$ : Vektor Orthogonal

$C_{\text {iy }}$ : Faktor Korelasi antara indeks term ke-i dengan minterm $r$

Sedangkan faktor korelasi dapat dinyatakan pada persamaan 2 .

$$
C_{i Y Y}=\Sigma_{d j] g i\left(d_{\eta}\right]=g i(M r)} W_{i j j}
$$

$$
\begin{array}{ll}
\text { Dimana : } & \\
W_{\mathrm{i} j} & : \text { Vektor dokumen ke-i } \\
g i(M r) \quad: \text { Bobot index term } K_{\mathrm{i}} \text { dalam } \\
\text { minterm } M_{r}
\end{array}
$$

f) Mengubah dokumen dan query menjadi vektor. Untuk menghitung nilai similaritas atau kemripan dokumen dan query, maka dokumen dan query harus diubah menjadi vektor terlebih dahulu. Untuk merubah dokumen dan query menjadi vektor menggunakan persamaan 3 dan 4.

$$
\begin{aligned}
& \overrightarrow{d_{j}}=\sum_{i=1}^{n} W_{i_{j} j} x \overrightarrow{K_{\mathrm{i}}} \\
& \vec{q}=\sum_{\mathrm{i}=1}^{\mathrm{n}} q_{\mathrm{i}} x \overrightarrow{K_{\mathrm{i}}}
\end{aligned}
$$

Dimana :

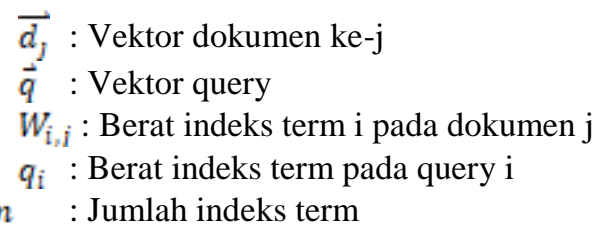

g) Menghitung nilai similaritas dokumen menggunakan perkalian vektor menggunakan persamaan 5

$$
\operatorname{sim}\left(\overrightarrow{d_{j}}, \vec{q}\right)=\frac{\overrightarrow{d_{j}} \cdot \vec{q}}{\left|\overrightarrow{d_{j}}\right||\vec{q}|}
$$

Dimana :

$$
\begin{array}{ll}
\overrightarrow{d_{g}} & : \text { Vektor dokumen ke-j } \\
\frac{\vec{q}}{\mathrm{a}} & : \text { Vektor query }
\end{array}
$$

\subsection{Naïve Bayes Classifier}

Selain proses pencarian sinopsis pada penelitian ini juga terdapat proses klasifikasi. Proses klasifikasi dilakukan jika terdapat sinopsis baru yang belum mempunyai kelas. Untuk proses klasifikasi digunakan metode naïve bayes sebagai metode klasifikasi.

Sebuah bayes classifier adalah classifier probabilistik sederhana berdasarkan penerapan teorema Bayes (dari statistik Bayesian) dengan asumsi independen (naif) yang kuat. Sebuah istilah yang lebih deskriptif untuk model probabilitas yang digaris bawahi adalah "model fitur independent".

Dari proses ekstraksi data selanjutnya dilakukan pemodelan untuk mengelompokkan berdasarkan kategori. Untuk implementasi data tersebut kedalam model algoritma naïve bayes adalah dengan membuat tabel term document matrix dan selanjutnya akan ditentukan nilai probabilitas untuk masing-masing kategori seperti ditunjukkan pada persamaan 6 .

$$
P\left(W_{j k} \mid C_{i}\right)=\frac{f\left(W_{j k}, C_{i}\right)+1}{f\left(C_{i}\right)+|W|}(2)
$$

Dimana :

$P\left(W_{i k} \mid C_{i \mathrm{i}}\right)=$ Nilai kemunculan kata $\mathrm{Wjk}$ pada kategori $\mathrm{Ci}$

$f\left(C_{i}\right)=$ Jumlah keseluruhan kata pada kategori $\mathrm{Ci}$ $|\mathrm{W}|=$ Jumlah keseluruhan kata atau fitur yang digunakan.

Kemudian dilakukan perhitungan TF-IDF dengan persamaan 7 .

$\mathrm{P}\left(\mathrm{C}_{\mathrm{i}}\right)=\frac{\operatorname{fd}\left(\mathrm{C}_{\mathrm{i}}\right)}{\|\mathrm{D}\|}$

Dimana :

$f d\left(C_{i}\right)=$ Jumlah dokumen yang memiliki kategori $\mathrm{Ci}$

|D $\quad=$ Jumlah seluruh training dokumen

Sedangkan untuk klasifikasi bentuk naïve băyes digunakan persamaan 8 .

$$
\begin{aligned}
& C *= \operatorname{argmax} p\left(C_{i \mathrm{i}} \mid d_{i j}\right) \\
&\left.\quad=\operatorname{argmax} \prod p\left(W_{k j} \mid C_{i}\right) \times p\left(C_{i}\right)^{4}\right)
\end{aligned}
$$


Dimana $W_{k \tilde{f}}$ merupakan fitur atau kata dari dokumen $d_{f}$ yang ingin diketahui kategorinya. Nilai $p\left(C_{i} \mid d_{j}\right)$ dipelajari dari data training yang dimiliki dengan menggunakan informasi jenis fitur yang berbeda.

\subsection{Recall dan Precision}

Recall dan precision digunakan untuk mengukur efektifitas kinerja dari suatu information retrieval. Recall adalah perbandingan antara jumlah dokumen relevan yang ditampilkan terhadap jumlah seluruh dokumen yang relevan (Nisa Putri, 2016). Perhitungan recall menggunakan persamaan 9 .

recall $=\frac{\#(\text { relevant items retrieved })}{\#(\text { relevant items })}$

Precision adalah perbandingan antara jumlah dokumen relevan yang ditampilkan terhadap jumlah seluruh dokumen yang ditampilkan. Perhitungan precision dinyatakan dengan persamaan 10 .

precision $=\frac{\#[\text { relewant items retrieved] }}{\#[\text { retrieved items] })}$

Penotasian precision dan recall dalam bentuk contingency table ditunjukkan pada tabel 2 .

Tabel 2. Contingency table precision dan recall

\begin{tabular}{|l|l|l|}
\hline & Relevant & Non Relevant \\
\hline Retrieved & $\begin{array}{l}\text { True Positives } \\
\text { (tp) }\end{array}$ & $\begin{array}{l}\text { False Positives } \\
(\mathrm{fp})\end{array}$ \\
\hline $\begin{array}{l}\text { Non } \\
\text { Retrieved }\end{array}$ & $\begin{array}{l}\text { False } \\
\text { Negatives (fn) }\end{array}$ & $\begin{array}{l}\text { True Negatives } \\
(\mathrm{tn})\end{array}$ \\
\hline
\end{tabular}

Dari tabel 2 diperoleh sebuah persamaan untuk menghitung precision dan recall, seperti ditunjukkan pada persamaan 11 dan 12 .

$\begin{aligned} \text { Precision } & =\frac{t p}{(t p+f p)} \\ \text { Precision } & =\frac{t p}{(t p+f n)}\end{aligned}$

\section{UJI COBA DAN HASIL}

Berikut ini merupakan hasil uji coba yang telah dilakukan pada penelitian ini.

\subsection{Pencarian dengan Metode Generalized Vector Space Model (GVSM)}

Dengan menggunakan perhitungan algoritma generalized vector space model, terdapat sebuah query serta 5 dokumen seperti terlihat pada tabel 3 .

\section{Tabel 3. Query dan dokumen}

\begin{tabular}{|c|l|}
\hline Query & \multicolumn{1}{|c|}{ Libur Rumah Nenek Teman } \\
\hline D1 & $\begin{array}{l}\text { nenek rumah grettel marrie marsya } \\
\text { kejut izumi senyum bagaiman temu ada } \\
\text { apa libur teman ajak dekat nenek } \\
\text { sampai izumi-jepang }\end{array}$ \\
\hline
\end{tabular}

Tabel 3. Lanjutan

\begin{tabular}{|l|l|}
\hline Query & Libur Rumah Nenek Teman \\
\hline D2 & $\begin{array}{l}\text { aduh diari sedih malu-maluin senang teri } \\
\text { pokok unik benar-benar lugu lucu } \\
\text { sulthan seru kocaaak banget sd anak } \\
\text { hihihi hari-harinya kerap hahaha gokil } \\
\text { konyol isi alam }\end{array}$ \\
\hline D3 & $\begin{array}{l}\text { amelia hutan teman ambar sentanu } \\
\text { meneganggkan baru petualangan angker } \\
\text { genderuwo tengah mati takut warga } \\
\text { percaya benar nenek dikenalnya ski } \\
\text { sepupunya temu maya berhasil mama } \\
\text { izin kakek dunia desa rumah bersikeras } \\
\text { libur sana }\end{array}$ \\
\hline D4 & $\begin{array}{l}\text { marina renata benar baca jessica kamu } \\
\text { tarik yuk cerita-cerita tunggu buku temu } \\
\text { tindas artis banget senang idola sahabat } \\
\text { tivi benci sebentar }\end{array}$ \\
\hline D5 & $\begin{array}{l}\text { dunia siapa si mimpi nyata untung } \\
\text { panggil dewasa sweets artinya ikut ingin } \\
\text { magic ingin orang-orang pemilik sack } \\
\text { biasa nama sempurna indah kadang hani } \\
\text { kalista hitung hadir sma siswi pukau }\end{array}$ \\
\hline
\end{tabular}

Dari tabel 3 diatas telah dilakukan tahap preprocessing yang meliputi case folding dan tokenizing, filtering serta stemming.

Setelah tahap preprocessing maka selanjutnya dilakukan proses untuk menghitung bobot setiap term menggunakan TF-IDF. Hasil perhitungan TFIDF dapat dijelaskan pada tabel 4

Tabel 4. Perhitungan nilai idf

\begin{tabular}{|c|c|c|c|c|c|c|c|c|c|}
\hline \multirow{2}{*}{ Term } & \multicolumn{6}{|c|}{ TF } & \multirow{2}{*}{$\begin{array}{l}\mathrm{d} \\
\mathrm{f}\end{array}$} & \multirow{2}{*}{$\begin{array}{l}\mathrm{d} / \mathrm{d} \\
\mathrm{f}\end{array}$} & \multirow[b]{2}{*}{ Idf } \\
\hline & $\mathrm{Q}$ & $\begin{array}{l}\mathrm{D} \\
1\end{array}$ & $\begin{array}{l}\mathrm{D} \\
2\end{array}$ & $\begin{array}{l}\mathrm{D} \\
3\end{array}$ & $\begin{array}{l}\mathrm{D} \\
4\end{array}$ & $\begin{array}{l}\mathrm{D} \\
5\end{array}$ & & & \\
\hline Libur & 1 & 1 & 0 & 1 & 0 & 0 & 2 & 2,5 & $\begin{array}{l}0,39 \\
79\end{array}$ \\
\hline $\begin{array}{l}\text { Ruma } \\
\text { h }\end{array}$ & 1 & 4 & 0 & 1 & 0 & 0 & 5 & 1,0 & 0 \\
\hline Nenek & 1 & 4 & 0 & 1 & 0 & 0 & 5 & 1,0 & 0 \\
\hline Teman & 1 & 1 & 0 & 2 & 0 & 0 & 3 & 1,7 & $\begin{array}{l}0,22 \\
18 \\
\end{array}$ \\
\hline
\end{tabular}

Tabel 4 merupakan hasil hasil perhitungan IDF dari 4 term yang ada. Kolom df pada term "libur" diperoleh dari jumlah dokumen yang mengandung term "libur" yaitu sebanyak 2 dokumen. Setelah dilakukan perhitungan nilai IDF, selanjutnya dilakukan perhitungan nilai bobot (W). Hasil perhitungan bobot dapat dilihat pada tabel 5 .

Tabel 5. Perhitungan nilai $w$

\begin{tabular}{|l|c|c|c|c|c|c|}
\hline \multirow{2}{*}{ Term } & \multicolumn{7}{|c|}{ W } \\
\cline { 2 - 7 } & Q & D1 & D2 & D3 & D4 & D5 \\
\hline Libur & 1 & 1 & 0 & 1 & 0 & 0 \\
\hline Rumah & 1 & 4 & 0 & 1 & 0 & 0 \\
\hline Nenek & 1 & 4 & 0 & 1 & 0 & 0 \\
\hline Teman & 1 & 1 & 0 & 2 & 0 & 0 \\
\hline
\end{tabular}

Tabel 5 merupakan hasil perhitungan nilai W yang diperoleh dari jumlah term pada setiap dokumen dikalikan dengan nilai IDF. Untuk term 
"libur" pada D1 terdapat 1 term, diperoleh nilai $\mathrm{W}=$ 1 x 0,3979 dan seterusnya untuk term yang lain.

Sesuai dengan perhitungan algoritma generalized vector space model terdapat 6 langkah dalam menyelesaikan proses pencarian sebagai berikut

a) Melakukan preprocessing berupa case folding, tokenizing, filtering, dan stemming

b) Menentukan pola minterm yang muncul sesuai dengan query yang diinputkan oleh user. Dalam penelitian ini penulis menggunakan 4 kata kunci yaitu Libur, Rumah, Nenek, Teman. Sehingga pola minterm yang terbentuk dijelaskan pada tabel 6 .

Tabel 6. Pola minterm

\begin{tabular}{|c|c|}
\hline Pola minterm & Term query \\
\hline$M_{w}$ & Libur \\
\hline$M_{x}$ & Rumah \\
\hline$M_{y}$ & Nenek \\
\hline$M_{s}$ & Teman \\
\hline
\end{tabular}

c) Hasil perhitungan bobot (W) pada tabel 5 digunakan nilainya kedalam bentuk vektor orthogonal berdasarkan pola minterm yang sudah terbentuk. Penentuan bentuk vektor orthogonal dijelaskan pada tabel 7

Tabel 7. Penentuan vektor orthogonal

\begin{tabular}{|l|l|l|l|l|l|}
\hline $\begin{array}{l}\text { Do } \\
\mathrm{k}\end{array}$ & Libur & $\begin{array}{l}\text { Ruma } \\
\mathrm{h}\end{array}$ & $\begin{array}{l}\text { Nene } \\
\mathrm{k}\end{array}$ & $\begin{array}{l}\text { Tema } \\
\mathrm{n}\end{array}$ & $\begin{array}{l}\text { Vektor } \\
\text { Orthogon } \\
\mathrm{al}\end{array}$ \\
\hline D1 & $\begin{array}{l}0,397 \\
9\end{array}$ & 0 & 0 & $\begin{array}{l}0,221 \\
8\end{array}$ & $\overrightarrow{M_{1}}$ \\
\hline D2 & 0 & 0 & 0 & 0 & $\overrightarrow{M_{4}}$ \\
\hline D3 & $\begin{array}{l}0,397 \\
9\end{array}$ & 0 & 0 & $\begin{array}{l}0,443 \\
7\end{array}$ & $\overrightarrow{M_{M}}$ \\
\hline D4 & 0 & 0 & 0 & 0 & $\overrightarrow{M_{4}}$ \\
\hline D5 & 0 & 0 & 0 & 0 & $\overrightarrow{M_{4}}$ \\
\hline Q & $\begin{array}{l}0,397 \\
9\end{array}$ & 0 & 0 & $\begin{array}{l}0,221 \\
8\end{array}$ & \\
\hline
\end{tabular}

d) Setelah vektor orthogonal tebentuk selanjutnya adalah menghitung nilai index term. Untuk menghitung index term menggunakan persamaan 1. Dalam menghitung index term terlebih dahulu harus diketahui nilai faktor korelasi setiap term. Faktor korelasi dapat dihitung menggunaka persamaan 2. Nilai faktor korelasi yang digunakan adalah korelasi antara query dengan dokumen. Hasil dari faktor korelasi dapat dilihat pada tabel 8 .

Tabel 8. Perhitungan faktor korelasi

\begin{tabular}{|l|l|l|l|}
\hline$C_{1,1}=0,3979$ & $C_{2,1}=0$ & $C_{2,1}=0$ & $C_{4,1}=0,2218$ \\
\hline$C_{1,2}=0$ & $C_{2,2}=0$ & $C_{2,2}=0$ & $C_{4,2}=0$ \\
\hline$C_{1,3}=0,3979$ & $C_{2,3}=0$ & $C_{2,3}=0$ & $C_{4,3}=0,4437$ \\
\hline$C_{1,4}=0$ & $C_{2,4}=0$ & $C_{3,4}=0$ & $C_{4,4}=0$ \\
\hline$C_{1,5}=0$ & $C_{2,5}=0$ & $C_{2,5}=0$ & $C_{4,5}=0$ \\
\hline
\end{tabular}

Dari faktor korelasi tabel 8 diatas, selanjutnya digunakan untuk menghitung nilai index term menggunakan persamaan 1 . Hasil perhitungan index term dijelaskan pada tabel 9

Tabel 9. Nilai index term

\begin{tabular}{|l|l|}
\hline & Index Term \\
\hline $\mathrm{K} 1$ & $\overrightarrow{K_{1}}=\frac{0,3979 \overline{M_{1}}+0,3979 \overline{M_{3}}}{\sqrt{0,3166}}$ \\
\hline $\mathrm{K} 2$ & $\overrightarrow{K_{2}}=\frac{0}{\sqrt{0}}$ \\
\hline $\mathrm{K} 3$ & $\overrightarrow{K_{3}}=\frac{0}{\sqrt{0}}$ \\
\hline $\mathrm{K} 4$ & $\overrightarrow{K_{4}}=\frac{0,2218 \overline{M_{1}}+0,4437 \overline{M_{3}}}{\sqrt{0,2461}}$ \\
\hline
\end{tabular}

e) Merubah dokumen dan query kedalam bentuk vektor menggunakan persamaan 3 dan 4. Hasil perhitungan vektor dokumen dan vektor query dijelaskan pada tabel 10

Tabel 10. Perhitungan vector dokumen dan query

\begin{tabular}{|l|l|l|l|l|l|l|}
\hline \multirow{2}{*}{ Dok } & \multicolumn{5}{|c|}{ Vektor Dokumen } & \multirow{2}{*}{ Q } \\
\cline { 2 - 6 } & D1 & D2 & D3 & D4 & D5 & \\
\hline D1 & 0,380 & 0,000 & 0,479 & 0,000 & 0,000 & 0,38 \\
& 6 & 0 & 8 & 0 & 0 & 06 \\
\hline D2 & 0,000 & 0,000 & 0,000 & 0,000 & 0,000 & 0,00 \\
& 0 & 0 & 0 & 0 & 0 & 00 \\
\hline D3 & 0,479 & 0,000 & 0,678 & 0,000 & 0,000 & 0,47 \\
& 8 & 0 & 2 & 0 & 0 & 98 \\
\hline D4 & 0,000 & 0,000 & 0,000 & 0,000 & 0,000 & 0,00 \\
& 0 & 0 & 0 & 0 & 0 & 00 \\
\hline D5 & 0,000 & 0,000 & 0,000 & 0,000 & 0,000 & 0,00 \\
& 0 & 0 & 0 & 0 & 0 & 00 \\
\hline
\end{tabular}

f) Setelah dokumen dan query diubah menjadi vektor, selanjutnya adalah menghitung nilai similaritas dokumen dan query menggunakan persamaan 5. Hasil perhitungan nilai similaritas dokumen dan query dijelaskan pada tabel 11

Tabel 11. Nilai similaritas dokumen

\begin{tabular}{|c|c|}
\hline Dokumen & Nilai Similaritas \\
\hline D1 & 1,000 \\
\hline D2 & 0,000 \\
\hline D3 & 0,998 \\
\hline D4 & 0,000 \\
\hline D5 & 0,000 \\
\hline
\end{tabular}

Dari nilai Cosine Similarity dan Peringkat yang diperoleh pada tabel 11, ada tiga dokumen yang mempunyai nilai 0 , sehingga dokumen tersebut tidak ditampilkan dalam hasil. Sedangkan dokumen yang ditampilkan oleh IR sistem kepada user (pengguna) urut berdasarkan pringkatnya adalah dokumen D1 dan Dokumen D3. 


\subsection{Uji Coba pada Sistem}

a) Unit Testing

Terdapat tiga komponen utama dalam pengujian pencarian, yaitu uji coba input keyword, proses, dan hasil. Dalam setiap pengujian blackbox, penguji akan melihat perubahan yang ada dalam database dengan bantuan software database management.

1. Uji Coba Input Keyword Input teks yang akan digunakan untuk uji coba seperti pada table 12 berikut ini

Tabel 12. Keyword pencarian

\begin{tabular}{|l|l|}
\hline No & Keyword Text \\
\hline 1 & Berlibur kerumah nenek bersama teman \\
\hline 2 & 99 cahaya dilangit eropa \\
\hline 3 & Jutawan tewas terbunuh \\
\hline 4 & Fenomena boyband \\
\hline 5 & Buku diari gembel \\
\hline 6 & Hidung besar seperti pinokio \\
\hline 7 & Rahasia hati siti hajar \\
\hline 8 & Knife dan ratu peri pemberani \\
\hline 9 & Romeo dan juliet \\
\hline 10 & Takdirku telah terukir dilangit \\
\hline
\end{tabular}

Jika user akan melakukan pencarian maka user akan masuk ke menu Input Keyword, kemudian teks keyword akan otomatis masuk kedalam tabel buku. Tampilan input keyword seperti tampak pada gambar 3 berikut :

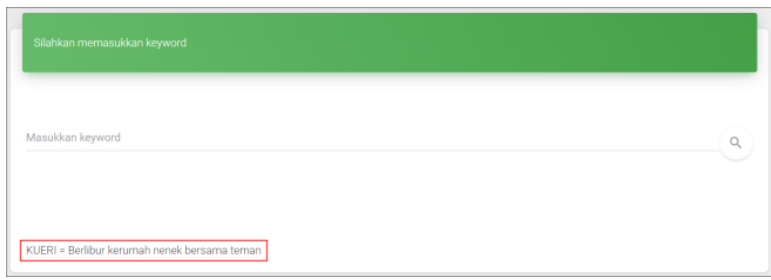

Gambar 3. Halaman input keyword pencarian

Uji coba tampilan pada tabel buku setelah proses input keyword dilakukan ditunjukkan pada gambar 4 berikut

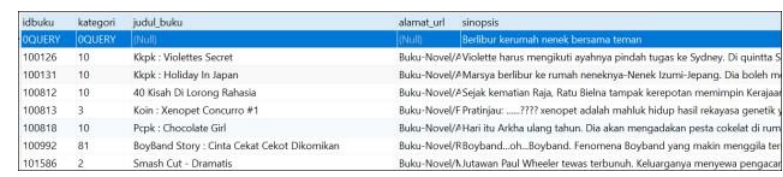

Gambar 4. Tabel buku update keyword

2. Uji Coba Proses Pencarian

Tampilan pada uji coba proses hanya merupakan keterangan dan hasil perhitungan. Namun untuk uji coba keberhasilan terletak pada tabel-tabel yang digunakan sebagai perhitungan. Berikut merupakan tahap proses dan hasil yang terdapat dalam tabel.

Hasil yang didapatkan dalam tabel hitung seperti pada Gambar 5 dibawah ini

\begin{tabular}{|llcl|}
\hline did & term & tf & tfidf \\
OQUERY & teman & 1 & 1 \\
OQUERY & nenek & 1 & 1 \\
OQUERY & rumah & 1 & 1 \\
OQUERY & libur & 1 & 1 \\
100126 & violette & 5 & 0 \\
100126 & maker & 3 & 0 \\
100126 & trouble & 3 & 0 \\
100126 & rahasia & 2 & 0 \\
100126 & ganggu & 2 & 0 \\
100126 & marah & 1 & 0 \\
100126 & heran & 1 & 0 \\
100126 & ikut & 1 & 0 \\
100126 & tetap & 1 & 0 \\
100126 & cari & 1 & 0 \\
100126 & yuk & 1 & 0 \\
100126 & tenang & 1 & 0 \\
\hline
\end{tabular}

\section{Gambar 5. Hasil Uji Coba Term pada Tabel Hitung}

Dari hasil uji coba, terdapat beberapa kelemahan yaitu pada proses pemenggalan kata menjadi kata dasar tidak berjalan sempurna, beberapa kata belum dapat dijadikan sebagai kata dasar. Sehingga akan mempengaruhi jumlah term frequency jika imbuhan berbeda namun memiliki kata dasar sama. Proses pengambilan term pada tiap dokumen terdapat pada pre-process.php. Hasil yang didapatkan dalam tabel hitung seperti pada Gambar 5 dibawah ini

\begin{tabular}{|lllr|}
\hline idhitung & did & term & tf \\
OQUERY_teman & OQUERY & teman & 1 \\
OQUERY_nenek & OQUERY & nenek & 1 \\
OQUERY_rumah & OQUERY & rumah & 1 \\
OQUERY_libur & OQUERY & libur & 1 \\
100126_violette & 100126 & violette & 5 \\
100126_maker & 100126 & maker & 3 \\
100126_trouble & 100126 & trouble & 3 \\
100126_rahasia & 100126 & rahasia & 2 \\
100126_ganggu & 100126 & ganggu & 2 \\
100126_marah & 100126 & marah & 1 \\
100126_heran & 100126 & heran & 1 \\
100126 ikut & 100126 & ikut & 1 \\
\hline
\end{tabular}

\section{Gambar 6. Hasil uji coba tf pada tabel hitung}

Proses menghitung index term pada setiap dokumen dapat dilihat pada gambar berikut ini

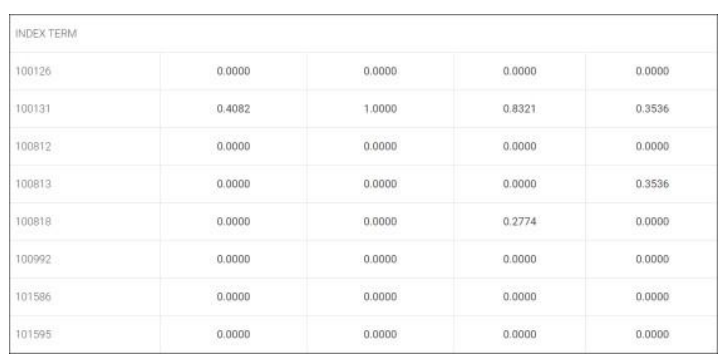

Gambar 7. Hasil perhitungan index term

Proses perhitungan index term digunakan untuk menghitung indeks term pada setiap dokumen untuk masing - masing kata kunci yang digunakan. Nilai indeks term dokumen $\mathbf{1 0 0 1 2 6}$ terhadap kata kunci "LIBUR", "NENEK", "RUMAH" dan 
"TEMAN". Proses menghitung kemiripan dokumen terhadap query dapat ditampilkan pada Gambar dibawah

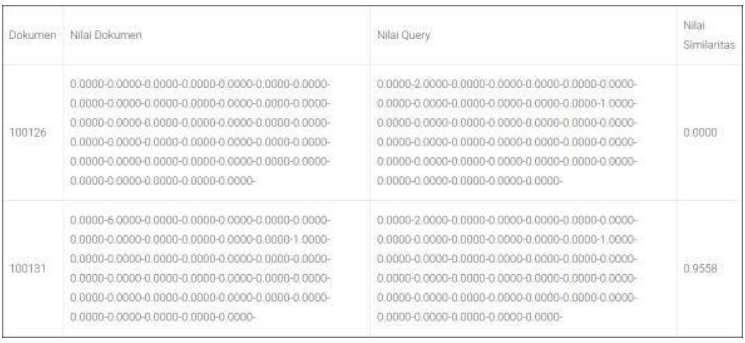

Gambar 8. Proses uji coba perhitungan kemiripan dokumen

Proses perangkingkan dokumen digunakan untuk mengurutkan nilai dokumen secara descending, tampilan perangkingan dokumen dapat dilihat pada Gambar dibawah ini

\begin{tabular}{|lr|}
\hline idbuku & \multicolumn{1}{c|}{ similar } \\
\hline 100131 & 0,9558 \\
\hline 100818 & 0,8944 \\
102561 & 0,4472 \\
112562 & 0,4472 \\
133990 & 0,8944 \\
143999 & 0,8944 \\
144224 & 0,8944 \\
\hline
\end{tabular}

\section{Gambar 9. Proses uji coba perhitungan kemiripan dokumen}

\section{Uji Coba Proses Klasifikasi}

Proses pertama sebelum dilakukan klasifikasi adalah menginputkan keyword berupa sinopsis novel bahasa Indonesia yang akan diklasifikasikan. Proses ini sama dengan proses pada input keyword untuk pencarian. Proses input dapat dilihat pada gambar 10 berikut ini

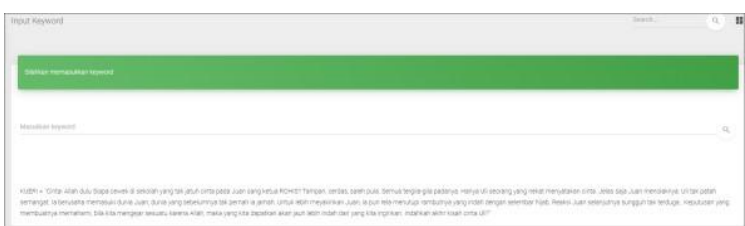

\section{Gambar 10. Input keyword sinopsis klasifikasi}

Dalam proses perhitungan selanjutnya, setiap dokumen akan dihitung jumlah kemunculan pada setiap term, proses ini dapat dijelaskan pada gambar 11 berikut ini.

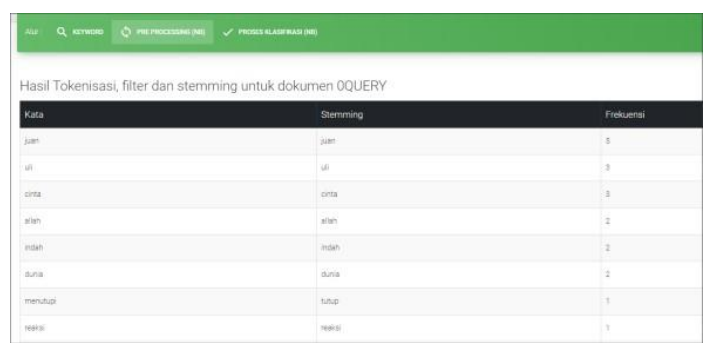

Gambar 11. Perhitungan term frequency
Pada proses ini dilakukan menggunakan metode naïve bayes sesuai dengan rumus perhitungan metode tersebut. Seperti tampak pada gambar 12 berikut ini.

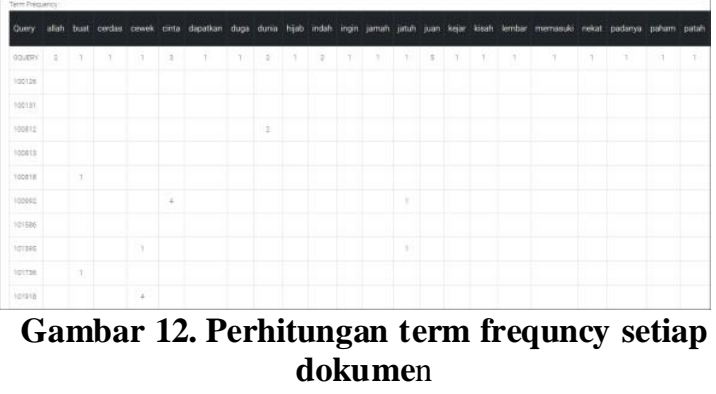

Pada proses selanjutnya dihitung probabilitas yang akan menentukan keyword yang telah dimasukkan masuk dalam kategori apa seperti pada gambar 13 dibawah ini

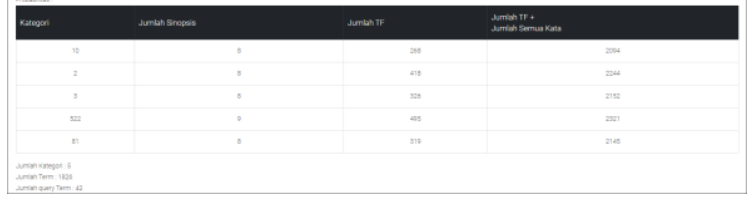

Gambar 13. Jumlah term setiap dokumen

Setelah dilakukan proses perhitungan maka program akan menghasilkan nilai tertinggi dalam setiap kategori seperti tampak pada gambar 14 berikut ini

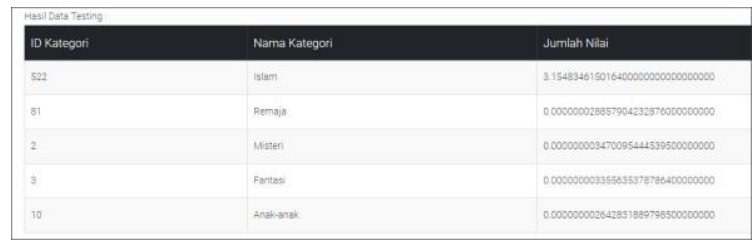

Gambar 14. Hasil nilai probabilitas setiap kategori

b) Hasil Uji Coba Pencarian

Dari 150 keyword pencarian yang telah diproses dengan menggunakan 700 dokumen didapatkan hasil dokumen yang relevan sesuai dengan query atau keyword seperti pada tabel dibawah ini. Pada tabel 13 dibawah ini berjumlah 30 keyword dari total 150 data yang telah diuji

Tabel 13. Dokumen yang ditampilkan system

\begin{tabular}{|c|l|c|}
\hline No & \multicolumn{1}{|c|}{ Keyword } & $\begin{array}{c}\text { Jml } \\
\text { Dok }\end{array}$ \\
\hline 1 & Tadabbur Cinta & 24 \\
\hline 2 & $\begin{array}{l}\text { Xenopet adalah makhluk hidup hasil } \\
\text { rekayasa }\end{array}$ & 19 \\
\hline 3 & Perang nuklir yang menghancurkan dunia & 62 \\
\hline 4 & Mereka menjulukinya malaikat kematian & 54 \\
\hline 5 & Pegasus adalah teman yang sempurna & 36 \\
\hline 6 & Takdirku telah terukir dilangit & 28 \\
\hline 7 & Summer hantu perempuan dihotel & 58 \\
\hline 8 & Negara ravka shadow fold alina dan grisha & 19 \\
\hline 9 & Diana putri ratu amazon & 46 \\
\hline 10 & Berlibur kerumah nenek bersama teman & 113 \\
\hline
\end{tabular}


Tabel 13. Lanjutan

\begin{tabular}{|c|l|c|}
\hline 11 & Arkha mengadakan pesta coklat & 22 \\
\hline 12 & Rena punya ibu baru & 36 \\
\hline 13 & Marina bertemu artis idolanya & 18 \\
\hline 14 & Hidung besar seperti pinokio & 6 \\
\hline 15 & Kerajaan vickhara dan prince ghifari & 18 \\
\hline 16 & Cher yang tomboi dan suka dance & 19 \\
\hline 17 & Nindya berkhayal menjadi peri & 11 \\
\hline 18 & Petualangan iza dan teman-teman & 45 \\
\hline 19 & 99 cahaya dilangit eropa & 14 \\
\hline 20 & Kisah fatimah az-zahrah & 38 \\
\hline 21 & Rahasia hati siti hajar & 58 \\
\hline 22 & Masa lalu masa kini dan masa depan & 0 \\
\hline
\end{tabular}

Diperoleh jumlah dokumen yang sesuai dengan masing-masing query. Sebagai contoh untuk query "Takdirku telah terukir dilangit" diperoleh 28 dokumen. Sedangkan untuk query "Berlibur kerumah nenek bersama teman" diperoleh 113 dokumen. Untuk menghitung precision dan recall dibutuhkan sudut pandang pakar untuk menilai dokumen yang relevan berdasarkan keyword.

\section{c) Precision dan Recall}

Dari Uji coba yang telah dilakukan terhadap 700 dokumen sinopsis dengan 150 data keyword, serta telah didapatkan hasil dari sudut pandang pakar, maka perhitungan precision recall dari ke 150 data uji tersebut dapat dijelaskan pada tabel 14.

Tabel 14. Hasil perhitungan precision

\begin{tabular}{|c|l|c|c|}
\hline No & \multicolumn{1}{|c|}{ Kata Kunci } & Precision & Recall \\
\hline 1 & Tadabbur Cinta & $79 \%$ & $69 \%$ \\
\hline 2 & $\begin{array}{l}\text { Xenopet adalah } \\
\text { makhluk hidup hasil } \\
\text { rekayasa }\end{array}$ & $79 \%$ & $95 \%$ \\
\hline 3 & $\begin{array}{l}\text { Perang nuklir yang } \\
\text { menghancurkan dunia }\end{array}$ & $85 \%$ & $81 \%$ \\
\hline 4 & $\begin{array}{l}\text { Mereka menjulukinya } \\
\text { malaikat kematian }\end{array}$ & $89 \%$ & $82 \%$ \\
\hline 5 & $\begin{array}{l}\text { Summer hantu } \\
\text { Perempuan dihotel }\end{array}$ & $84 \%$ & $79 \%$ \\
\hline 6 & $\begin{array}{l}\text { Pegasus adalah teman } \\
\text { yang sempurna }\end{array}$ & $78 \%$ & $95 \%$ \\
\hline
\end{tabular}

Dari pengujian dengan 150 keyword dan terhadap 700 dokumen, pencarian tema sejenis sinopsis menggunakan metode generalized vector space model mendapatkan nilai rata-rata precision sebesar $85 \%$ dan rata-rata nilai recall sebesar $90 \%$.

\section{d) Hasil Uji Coba Klasifikasi}

Dalam uji coba klasifikasi pada laporan penelitian ini, penulis memproses data latih sebanyak 700 dokumen dan data uji sebanyak 150 dokumen seperti pada tabel berikut ini. Dari uji coba dokumen pada tabel 5.5 diperoleh tingkat akurasi sebesar $86 \%$ seperti ditunjukkan pada tabel berikut ini
Tabel 15. Akurasi uji coba klasifikasi

\begin{tabular}{|c|c|}
\hline Kategori & Jumlah \\
\hline Benar & 129 \\
\hline Salah & 21 \\
\hline Tingkat Akurasi & $86 \%$ \\
\hline
\end{tabular}

Secara garis besar proses klasifikasi dengan menggunakan metode naïve bayes pada penelitian ini telah berjalan dengan baik dan hasilnya sesuai dengan hipotesa pada penelitian ini, meski demikian ada beberapa hal yang menjadi catatan terkait dengan kesalahan dalam klasifikasi.

Secara garis besar hasil uji coba pada penelitian ini telah berjalan dengan baik. Dari perhitungan precision dan recall bahwa IR sistem dengan menggunakan metode generalized vector space model memiliki akurasi yaitu rata-rata nilai Recall 90\% dan Precision sebesar $85 \%$. Sedangkan untuk uji coba klasifikasi menggunakan metode naïve bayes juga berajalan cukup baik dengan tingkat akurasi mencapai $86 \%$ dan telah memenuhi harapan.

\section{KESIMPULAN}

Dari pembahasan sebelumnya serta berdasarkan uji coba terhadap sistem diambil kesimpulan antara lain :

1. Hasil uji coba pada penelitian ini menunjukkan hasil yang baik, pada proses pencarian dengan menggunakan metode Generalized Vector Space Model dari uji coba sebanyak 150 keyword dengan 700 data sinopsis nilai recall yang didapatkan sebesar $90 \%$ dan nilai precision sebesar $85 \%$.

2. Berdasarkan hasil pengujian lama waktu, pencarian dengan menggunakan metode generalized vector space model membutuhkan waktu yang sangat lama dikarenakan proses pencarian dengan metode gvsm membutuhkan waktu untuk mencari kedekatan makna antar term.

3. Dari penelitian yang telah dilakukan, faktor korelasi merupakan faktor yang membedakan antara metode gvsm dengan metode sebelumnya yaitu vector space model.

4. Hasil klasifikasi menggunakan metode naïve bayes pada penelitian ini mendapatkan hasil yang baik. Uji coba yang dilakukan dengan menggunakan 150 data uji dan 700 data training mendapatkan hasil akurasi sebesar $86 \%$.

5. Sinopsis yang didapatkan dengan cara crawling yang sudah terkategori otomatis pada data training sangat mempengaruhi hasil klasifikasi, banyak kategori sinopsis yang tidak sesuai dengan kategori yang semestinya.

6. Pada penelitian ini terdapat dua fitur sistem yang berbeda, fitur pencarian menggunakan metode gvsm dan fitur klasifikasi menggunakan metode naïve bayes. 


\section{PUSTAKA}

Baeza, Ricardo, B. Ribeiro. 1999. Modern Information Retrieval. ACM Press, United States of America.

Bunyamin Hendra, Chatalea Puspa Negara. 2008. Aplikasi Information Retrieval (IR) CATA dengan metode Generalized Vector Space Model. Bandung.

Digilib.unila.ac.id, diakses tgl. 3 April 2020 Pukul. 14.05 WIB.

I Made Suwija Putra, Ni Putu Ayu Widiardi, I Wayan Gunaya. 2019. Implementasi Generalized Vector Space Model dalam Pencarian Buku Diperpustakaan. Merpati, Vol (7): No 1.

Jasman Pardede, Mira Musrini Barnawi, Wildan Deny Pramono, 2013. Implementasi metode Generalized Vector Space Model pad Aplikasi Informastion Retrieval. Institut Teknologi Nasional Bandung. Bandung.

Junaedi Widjojo. 2012. Prediksi Jenis Kelamin dan Usia untuk Blog Berbahasa Indonesia dengan Metode Klasifikasi Teks yang Dilengkapi dengan Pemilihan Fitur Terbaik. Jurusan Teknologi Informasi, ISTTS, Surabaya.

Nisaa Putri Lestari. 2016. Uji Recall dan Precision Sistem Teтu Kembali Informasi OPAC Perpustakaan ITS Surabaya. Surabaya.

Suprianto, Sunardi, Abdul Fadlil, 2018. Aplikasi Sistem temu Kembali Angket Mahasiswa Menggunakan Metode Generalized Vector Space Model. Jurnal Teknologi Informasi dan Ilmu Komputer (JTIIK), Vol (6): No 1.

Tsatsaronis, G., Panagiotopoulou, 2009. A Generalized Vector Space Model for Text Retrieval Based on Semantic Relatedness, Proceedings of the EACL Student Research Workshop, Greece. 